\title{
MISCELLANEOUS
}

\section{There Is no Mercy}

\author{
In memoriam Sándor Loss
}

By IsTVÁn H. SZILÁGYI*

\begin{abstract}
This article offers a case study from the "law and literature" perspective implying the presentation of the legal material of the Pusoma case, the drama written from it by Elemér Magyar, the documentary film made from the case by Norbert Komenczi, and the film adaptation of the drama directed by Ragályi Elemér. The study concludes with indicating the directions of the further multidisciplinary studies involving literary studies, forensic linguistics, legal anthropology, criminology and legal sociology.
\end{abstract}

Keywords: Pusoma case, law and literature, law and film, multidisciplinary legal studies

\section{INTRODUCTION}

I first met the Pusoma case in 2007 when - together with my two colleagues - we delivered a course at the Hungarian Judicial Academy on the sociological problems of the judicature. One of my colleagues suggested using a scene as a didactical means from No Mercy - the film adaptation of the drama written from the case by Elemér Magyar and directed by Elemér Ragályi.

After this I realised that the Pusoma case offered itself as an excellent material for a complex, multidisciplinary case-study ${ }^{1}$ in which I could combine my previous research on the Hungarian Romas' legal position ${ }^{2}$ with various approaches of the "law and literature", legal anthropology, legal sociology and criminology.

If we take a closer look at the case from the perspective of "law and literature", several interesting problems come up: How do the stories told in the course of the legal process become established facts, which later turn out to be no less fictive then the plot of a detective novel? How does the legal material of a case become a literary work of art? How can a literary work affect the law and the legal community? At the same time, answers to these questions may reinforce the critical potential of the Hungarian legal theory and the

1 This study has been conducted within the frame of the TÁMOP-4.2.1.B-11/2/KMR-20110002 project.

2 István H. Szilágyi and Sandor Loss, 'Opening Scissors. The Legal Status of the Gypsy Minority in the Nowadays Hungary' (2002) 33/2-4 Rechtstheorie 483-494. István H Szilágyi, 'The Roma Way' in Anne Wagner and Vijay K. Bhatia (eds), Diversity and Tolerance in Socio Legal Context: Explorations in the Semiotics of Law (Ashegate 2009) 65-80.

*Associate professor, Pázmány Péter Catholic University. 
Hungarian "law and literature", which has been so painfully missing hitherto. ${ }^{3}$ This critical intention led me to choose the title for this paper.

I had the opportunity to discuss the previous versions of this paper at the IV ${ }^{\text {th }}$ Symposium for Law and Literature in Szeged, Hungary, on 25 May 2012 and at the $\mathrm{V}^{\text {th }}$ National Convention of the Italian Society of Law and Literature, Turin, Italy, on 17-18 June 2013. I would like to express my gratitude to Elemér Magyar and Norbert Komenczi - who made a documentary film, entitled Grinder, about the case - for their invaluable help in collecting data and to those colleagues who offered critical comments and advice, especially to Mátyás Bencze, Balázs Fekete, Anna Kiss and Tamás Nagy.

\section{A STORY}

What follows below is not "the" story. Since it ensues from the nature of human matters, namely that an action or a social event can never be repeated again, what we could only do - supposing that something had "really" happened, and it had happened objectively this or that way - is try to reconstruct the actions and events afterwards with our limited means relying on oral testimonies, written documents and physical evidence. The act of reconstruction can never be completely separated from the act of interpretation and that of explanation, and therefore, from the intentions of the person or community who does the reconstruction. Thus, the following story is not an account of the Pusoma case - as it "really" happened - but rather a presentation of a set of oral and written "sources" that might imply a series of possible and equally plausible events. The ways and means of this presentation, of course, are not independent either of the intentions or interpretations of the present author himself. ${ }^{4}$

To counterbalance (and cover) this, I have chosen the way of storytelling that first Bram Stoker used successfully in Dracula, in which there is not an omniscient narrator, but the story is unfolding from a collage of newspaper articles and diary notes. So what you will find below is an abridged review of the legal documents arisen from the Pusoma case. From time to time, other texts and information will be inserted, set in italics, taken from other sources - primarily from the above mentioned documentary film, the Grinder, and from newspaper articles - and also my notes in this file.

The legal documents have been provided by Elemér Magyar, who emphasized that the file is not complete. It had been passed from hand to hand several times when Magyar and Ragályi were working on No Mercy's screenplay, and even later on. Some documents got lost from the stock, while others have been incorporated in it. I tried to fill the hiatuses using other sources, but, in my opinion, the material presented below is reasonably enough to establish an authentic interpretation.

I shall call some persons who undertook the public appearance in the Grinder especially Elemér Magyar (EM) and Dénes Pusoma (DP) - by their real name. Others will be mentioned by the name they received in the film, while the officials who took part in the legal process by their titles.

3 István H. Szilágyi, 'Law and Literature in Hungary. An Introduction' (2012) 53/1 Acta Juridica Hungarica 1-6.

4 For an account of how this problem appears in a more general level in history see e.g. Hayden White, 'The burden of history' (1966) 5/2 History and Theory 111-134. Hayden White, Metahistory: The Historical Imagination in Nineteenth Century Europe (Johns Hopkins 1973). 
Primary School, Ivád, 14.00, 17 March 1994

Aunt Manci's (the opposite neighbour of the victim, Aunt Rozi) - 59 years old, retired - hearing as witness (1. round)

She saw two strangers passing towards the gypsy row around 4 o'clock on the previous afternoon. Later, around midnight, she saw three persons - a taller and two smaller ones who were not locals, and they also headed towards the gypsy row. (The real culprit probably had been among them as it later turned out.) She did not see a green car. Gypsies visited Aunt Rozi too, because she was helpful.

Mayor's office, Ivád. 15.50, 17 March 1994

Mrs Albert Pusoma's (DP's mother) - 73 years old, illiterate - hearing as witness (1. round)

DP was digging in the garden till 14.00 on the previous day, 16 March. Mrs Pusoma understood that he lent Aunt Rozi a hand, but she did not give him money. DP returned home around 3 p.m., and he did not go anywhere later. DP wore the same clothes all day.

Police station, Pétervására, 17.00, 17 March 1994

DP's - 28 years old (Roma), unemployed, single, childless - hearing as witness (1. round)

(In Grinder Dezsi - a friend of DP, with whom DP had been working at the Duna Cooperative at Csepel [Budapest], and had been DP's superior for 5 years - tells that the police brought him, together with DP, handcuffed to the police station, and they beat DP up, for he heard him "screaming awfully".)

On the previous day, 16 March, DP went out to bring water from the public well, and he saw that Dezsi was working at Aunt Rozi's place. DP offered him a hand. Aunt Rozi, some members of her family, and Dezsi had lunch together around 13.00. They did not invite him (DP) for the lunch, but Old Beni - Aunt Rozi's son-in-law - offered him a glass of wine. Neither Dezsi nor DP got any money for the work. DP left for home with Dezsi about 14.00. DP found a dead hen on the way back home that might have been hit by a car. He brought it home, and his mother cooked it. He did not go out anywhere after this.

He wore a dark blue overall and rubber boots.

On the way back home, he saw Aunt Rozi and her daughter talking at the gate in front of the house.

DP had not worked for Aunt Rozi for years, because she never gave money for it, or just little, even if he worked all day. Others used to work for her, too. After he parted from Dezsi, he did not meet him again later.

Mayor's office, Ivád, 19.00, 17 March 1994

Mrs Albert Pusoma's hearing as witness (2. round)

DP left around $11.00 \mathrm{He}$ arrived back at 12.30, and brought a dead hen. DP left again at 12.50 and returned at about 21.00 in the evening. He said he had been at Marika's place (DP's acquaintances). He wore an overall.

Primary school, Ivád, 11.00, 19 March 1994

Aunt Manci's hearing as witness (2. round)

On the day in question, Aunt Rozi's daughter and son-in-law, Old Beni, left Aunt Rozi at around 17.30. Then Aunt Rozi called Aunt Manci to the gate of her house and they had a 
chat for about 15 minutes. Going home, Aunt Manci heard the slamming of Aunt Rozi's veranda door, and she thought it was just Aunt Rozi going back into the house then.

Furthermore, Aunt Manci claims that she has a feeble-minded half-sister, Juliska, handicapped by a speech disorder, who is under her guardianship, and she lives in the neighbouring house. Juliska (later the crown witness in the trial) is sitting all day on the street, and she knows everybody and everything that happens in the neighbourhood. That very evening she told Aunt Manci that she had seen DP peeping through the apple trees by Aunt Rozi's house. Since then, Juliska has kept repeating she saw DP sneaking into Aunt Rozi's house while Aunt Rozi and Manci were chatting in front of the house.

Primary school, Ivád, 11.15, 19 March 1994

Aunt Juliska's hearing as witness (1. round)

DP came from the direction of the Eden pub, and he scurried into Aunt Rozi's house from the back, from the direction of the garden and the outdoor WC. She did not see him coming out of the house.

Police station, Pétervására, 13.00, 19 March 1994

DP's hearing as witness (2. round)

When he was working with Dezsi for Aunt Rozi, Old Beni invited him twice into the kitchen, and offered him wine. DP raked and hewed wood for about half an hour. He does not remember what he saw on the TV that night, but he mentions István Vágó's show, in which there are those exclamation marks. Aunt Rozi did not offer him anything. (DP becomes more and more exasperated and confused during the hearing. It can be read on page 6 of the police record: “...we were waiting that they may offer something, but they didn't offer anything. We went into the Old Fucking God.") He has not been at Aunt Rozi's place for two years. At that time he was in the cellar too, where Aunt Rozi offered him wine.

DP answers the question whether he has been at Aunt Rozi's house after this case (clearly misunderstanding it, seemingly thinking that the "case" in the question refers to the events which happened on 16 March) as follows: "I remember that I've dreamt something, but I can't get it now. I've had fears since then; I've been dreaming about her, Good God's beating me. I don't know, maybe I've two heads or something, but sometimes I see her, sometimes I don't. Sometimes I see her whole body lying on the floor, sometimes only the half of it. The right side of her face is more blood-stained, and she is lying on her side, in my dream, as I recall. The four legs of a table also appear nearby Aunt Rozi in my imagination.

Afterwards DP is asked whether he did return to Aunt Rozi to ask for some money. First he answers that he went back and asked for 300 HUF. But from the answer he has given to the questions inquiring about the details it seems that it is not clear for him whether this happened in his dream or in the reality: "WHAT HAPPENED AFTER THIS? The whole day has begun again; this has happened this way and, yes, that way. It has begun as it has been ended, that's all I can remember after that."

Primary school, Ivád, 10.55, 20 March 1994

Mrs Albert Pusoma's hearing as witness (3. round)

DP came back home at around 16.00 . He brought a hen, but it was already dead, so she did not cook it. DP left some time later, and he returned only at around 20.00. He told her that he had been at Aunt Bözsi's house (an acquaintance in the village) to look for some work. 
Mayor's office, Ivád, 13.00, 20 March 1994

DP's hearing as suspect (1. round) (The rubric for claiming lawyer's assistance has remained unfilled in the form of the police record.)

(This is DP's most collected testimony till then.) DP repeats what he had earlier said about Aunt Rozi, the work, returning home (14.00), finding and eating the dead hen. He did not leave his home after 16.00 .

Police station, Pétervására, 10.55, 21 March 1994

Mrs Albert Pusoma's hearing as witness (4. round) (DP is already suspected and detained.)

DP had assaulted her two times - "[...] but not as he had beaten me down to the ground, fucking Ivád!’. DP has some trouble with his mind - he had an accident - and he did not remember anything after the assault, and calmed down.

She and DP are living on 7.500 HUF per month. She has 180 HUF debt (the price of a loaf of bread and a pack of cigarettes) in the "upper" shop (which can be found on the upper end of the village), but she has a credit there, because they know she will pay the money back when she gets her pension.

On 16 March, when DP brought the hen, he had a pack of cigarettes that he had bought from the money he got from Aunt Bözsi. At around 17.00 he left again to Aunt Sári (another acquaintance in the village) and returned at 19.00. He washed himself and watched TV. He wore a blue overall and rubber boots.

\section{Heves County Police Headquarter, Eger, 21 March 1994}

Instruction ordering odour identification. The odour-leads were recorded at $17 \mathrm{March}$ in the victim's house. (The instruction does not describe precisely the part of the house where the odour-leads were recorded.)

Aunt Manci's house, Ivád, 11.00, 21 March 1994

Aunt Manci's hearing as witness (3. round)

Juliska saw DP sneaking into Aunt Rozi's house, and she mentioned it to her several times on that night, but she did not attach any importance to it.

Two days after the event, DP's mother - "Angel" as she is called in the village - went to Juliska asking what she had seen.

Budapest Police Headquarter, Budapest, 22 March 1994

Record of odour identification process.

During the process, five dogs have found the odour sample taken from the "area in front of the commode" identical. The dogs chose DP's sample from a pool of four samples in which there were three other persons' - who had been in the house, too - additional samples.

Heves County Police Headquarter, Eger, 15.50, 22 March 1994

DP's hearing as suspect (2. round)

At the beginning of the hearing, DP corroborates his confession he made on 20 March, and he puts forth the particulars in conformity with that.

DP is confronted with the results of the odour identification. DP keeps himself to his earlier statement, that is, he has not been in the living room, he does not know where Aunt Rozi kept her money, and he did not assault her. 
DP rejects the results of the polygraph test.

Then the officers begin to ask him about another, earlier homicide which happened in Ivád, about the murder of Old Joachim, the mushroom contractor. It becomes clear from the answers that he knows a lot of details of the case. DP emphasises that he could not commit the murder, because he abhors blood and mutilation.

He denies the perpetration of both murders.

Heves County Police Headquarter, Eger, 13.50, 30 March 1994

DP's hearing as suspect (3. round)

(DP is getting confused, but he does not plead guilty.) He does not remember his earlier confession. He does not remember what he did on 16 March. He makes a series of statements which attest to his disordered state of mind: "The angel and the devil both appear for me in my dream, both of them are me. [...] I already don't care about anything; it would be better even in the madhouse, there are, at least, nurses and cigs there."

Convict Prison, Eger, 31 May 1994

DP writes a letter with his own hand, in which he denies the committal of the murder.

Convict Prison, Eger, 1 June 1994

DP writes a letter with the same content as the one he wrote on the previous day, titled "The witness who became a pandour". (It is clear that he was not aware of the meaning of the word "pandour". He probably believed that it is a synonym for the suspect.)

Convict Prison, Eger, 10.45, 17 June 1994

DP's hearing as suspect (4. round)

He declines to make a confession as a suspect for he considers himself a witness.

Convict Prison, Eger, 19 June 1994

DP writes a letter, titled "Confession of guilt", in which he admits that he committed the crime, and he declares that he takes the responsibility for that. Unfortunately, this letter was not in the file, its content can be reconstructed only from the later judgment of the court.

Heves County Police Headquarter, Eger, 09.30, 19 September 1994

DP'S hearing as suspect (5. round)

(DP behaves the same way as three days earlier.) He is not willing to make a confession because he regards himself as being a witness.

Aunt Manci’s house, Ivád, 19 September 1994

Aunt Manci's hearing as witness

She declares that Aunt Juliska is mentally deficient, but she is a reliable witness. Whenever she asks Juliska, she always answers that she saw DP sneaking into Aunt Rozi's house.

Heves County Police Headquarter, Eger, 11.20, 11 October 1994

DP's hearing as suspect (6. round)

His letter, the "Confession of guilt" is shown to DP. He is denying his guilt; he is not willing to make any statement about the letter. 
Heves County Police Headquarter, Eger, 14 October 1994

Results of the psychiatric expert examination of Aunt Juliska.

According to the expert's opinion, her debility had already been certified during the process of her placement under guardianship in 1986. She has been re-examined in the course of the investigation of the crime on 8 July 1994, and she has been deemed imbecile (mentally deficient to a significant extent). Considering this, her testimony is ruled not acceptable. Nevertheless, on the basis of his own examinations, the appointed expert declares that her illness has "developed disproportionately", therefore her testimony can be accepted after all.

Heves County Prosecutor's Office, Eger, 5 December 1994

DP's hearing by the prosecutor (DP's assigned counsel is not present at this time. DP has not yet met him at any point.)

The prosecutor shows DP the excerpt about his dream in the record of the hearing of 19 March 1994. DP does not know how these parts have got into the record. He admits that he has written the "Confession of guilt", but he does not know why. "I think I wanted to attain something with it, but it didn't come together." He does not remember to whom he gave the letter. He does not react to the outcome of the odour identification. He denies his guilt.

Heves County Prosecutor's Office, Eger, 5 December 1994

Bill of indictment (The indictment gives a fairly concise summary of the established facts - it deals only briefly with the events preceding the crime and focuses on the description of the perpetration and the causes of death.)

According to the established facts, DP entered Aunt Rozi's house, and he demanded money from her. The victim denied that she had any money and wanted to expel him. DP did not believe that she had no money and assaulted her: he inflicted blows upon her head with mean and great force that lead to her losing consciousness. DP started to search the house afterwards, but he did not find the victim's 12,267 HUF kept at home. He did not take any valuables, and left the house. The victim, lying under the table in the kitchen, was found by a neighbour. The victim was transported to the hospital where she was properly treated, but her life could not be saved. The death was caused partly by previous illnesses - brain-softening, arteriosclerosis, myocardial degeneration - apart from the lesions caused by the assault. So, only an indirect causal relation can be established between the assault and the victim's death. DP is a psychopath, but his disordered personality does not preclude or limit his criminal liability. (To support this latter statement, a psychiatric expert's opinion was attached, but this is missing from the file, and its content can be reconstructed only from the trial's material.)

On the basis of the established facts, DP is indicted for bodily harm with fatal consequences and attempted robbery.

Heves County Court, Eger, 8.30, 20 January 1995

DP's first court session

In the course of recording DP's personal data, the court establishes that the Heves County Court, as appellate court, sentenced DP to one year in prison in April 1985 for disturbance of peace, causing grievous bodily harm, and other criminal offences. He was bound over on probation after nine months. (In the Grinder EM comments on the case and mentions that DP "played for real" after an insult by provoking a fellow in the pub.) 
DP denies his guilt, and declares that he does not want to make a confession.

During the presentation of the police investigation file, the presiding judge shows the crime evidence label attached to the file indicating that a tied up pack has been seized from XY (DP's cell mate). The pack contains the confession of guilt written in blue ink by DP. This evidence, which had been stored at the Financial Office of the Heves County Court up until the trial, is incorporated into the file now. The presiding judge rules the letter identical to the one DP handed over to XY. The presiding judge clarifies the fact that the odour lead was recorded in front of the commode, which was not in the kitchen, but in the living room. According to the file, DP was examined by psychiatric experts between 11 April and 1 May 1994.

$\mathrm{XY}$ witness tells that the police approached him in the prison to acquire information, and they threatened, blackmailed and offered him a reward for this purpose. Among others, XY tells: "Two investigating officers approached me in May. They wanted to know what kind of prank this boy had played. They said they understood that he got murder, and they wanted me to listen to everything he was to tell me about the crime. [...] The police told me that they would grant me a better place, if I was willing to cooperate. They told me too that if I helped them then they would set me free and I would defend myself at large. After this they told me if I didn't help them then they could charge me with connivance punishable by five years in prison at the most. [...] The detectives began with the murder of the old lady, and then asked me about the other old man's case. They talked about half a million, one million HUF that I could get, if I put them on track." Concerning the letter, XY tells: "I talked [...] to my defence lawyer. The accused told me that he too was in need of a lawyer, and he asked me to find one for him who could handle his case. The accused thought that I could be released earlier. The paper was wrapped in a kind of foil, I didn't read it, so I didn't know what was in it." XY discloses that he tried to appeal against the blackmail of the police to the Investigating Bureau with the help of his lawyer, but he failed.

The medical expert corroborates everything that has been said about the victim's injuries and the cause of death in the indictment.

\section{Heves County Court, Eger, 8.30, 25 January 1995}

DP's second court session

The court hears Aunt Manci and Juliska in the presence of psychiatric experts. Both women repeat their testimonies stated in the course of the investigation. Juliska is a reliable witness - she never lies -, she saw DP stepping over the fence and crossing the garden to the veranda of Aunt Rozi's house on the day in question.

The expert heard first, summarising his opinion, states that a correct testimony cannot be expected from Juliska due to her mental deficiency.

The second expert assumes the position that - in his opinion - Juliska's testimony is acceptable to all probability.

(Now a dispute is unfolding between the two psychiatric experts, in which also the medical expert, who was heard on the previous session, engages.) The medical expert calls attention to the problem that the witness might answer the purposefully posed questions with growing certainty, because an "involuntary learning" occurs in her in the course of the repeated hearings. He proposes for the court to order a new psychiatric examination of Aunt Juliska to clarify this problem. The court rules the supervision of the previous psychiatric opinions by the Institution for Forensic Medicine of the Medical University of Debrecen. (We shall hear about the outcome of this supervision in the judgment delivered later.) 
The second psychiatric expert submits his opinion about DP's criminal liability. According to this, a psychopathic personality structure can be observed in DP, with primitive characteristics. Numerous dissociative psychic mechanisms are working in his personality, a certain "psychogenic illusionistic paralogism" is setting in when the subject tries to terminate any unwanted personal contact. DP has no mental illness or disorder that can exclude his criminal liability.

The victim's daughter claims that Dezsi pruned the trees in the garden and DP helped him in the morning of the day in question. Her mother wanted to send him away, and she told him that he had not been called, so he would not get lunch either. Then Dezsi said that DP had come just to learn pruning. At lunch, Dezsi told that DP would like to come into the kitchen, and asked them to offer him a glass of wine, which the husband of the witness (Old Beni) did in fact. They left Ivád at 17.00. In answering the question of the presiding judge, the witness says that she knew where her mother kept the spare cash, and she used to count it when her mother was absent. According to the witness, about 2,000 HUF disappeared from the money-box kept in the kitchen at the time of the burglary. But the purse, which was usually kept near the money-box, had not been stolen, neither the money stored in the living room.

Dezsi corroborates his previous story including the episode of finding the dead hen. Answering a question, he tells that he had worked for Aunt Rozi on the day before the crime too, but DP had not been there that time. He usually got 2,000 HUF for work from the victim. He had got down payment, so he did not get money on the day in question. $\mathrm{He}$ returned to resume the pruning on the next morning. He saw Aunt Rozi's doctor and neighbour coming out of the house. The woman warned him not to go in the house, because "Aunt Rozi got into trouble!" The doctor said that he had called the ambulance and the police.

The woman, who lived in the house across the street, relates that she observed that Aunt Rozi's hens were out in the garden and the chimney did not smoke between 5.30 and 6 o'clock in the morning of 17 March 1994. "After this I went to see her, and when I arrived at the gate and reached for the key, I did not find it in its place. I tried the gate and it was open, and the key was in it. I went along to the vestibule and peeped in through the window of it, and I saw the victim lying under the table, moving her hand. I ran [...] (to her neighbour) and told her to come immediately. We went into the house then, and saw that every corner had been poked about. There was a wash basin in the middle of the kitchen, the basin stand was turned upside down, there were apples scattered around, and blood drops and hair in the wash sink; a bloody towel had been thrown into the centre of the kitchen. The glass of the cupboard window had been laid on the table. The room too had been rummaged through. The drawer of the commode had been pulled out and ransacked." Answering questions she mentions furthermore that the victim was lying under the table, and her head was pushed towards the couch. The neighbour called the doctor and phoned the victim's daughter. Dezsi opened the door of the veranda and inquired what had happened to Aunt Rozi, whether she was alive, conscious, but the witness did not let him in.

Old Beni corroborates his wife's testimony.

The bar woman of the Eden pub sets forth that she knows DP who usually behaved normal if he got money. "If somebody was pulling his leg, he easily became nervous. [...] If the accused was alone, he used to talk to himself."

The manager of the Eden pub asserts that he slept in the building of the pub on the night of 16 March 1994, and he heard barking around midnight. The dogs were barking towards the back of the premises (in the direction of the victim's garden), and he found 
unfamiliar footprints in the yard the next morning. He could tell this for his men were wearing military boots, while these tracks had been made by some kind of snow boots. The prints were of one or maybe two men. Anyway, he knows DP who was a regular patron of the pub. He was banned from the pub sometimes because of "his mouth", for he was menacing when he did not get credit.

Dezsi's wife relates that she sometimes borrowed money from Aunt Rozi, and Dezsi usually worked it off later.

Aunt Rozi's doctor reports that one neighbour called him around 8 o'clock in the morning of 17 March 1994, telling him that Aunt Rozi was ill. He recognised nothing unusual when he arrived at the house. (The two neighbours had already cleaned everything up. They had two hours for this. That is, the forensic experts could not record any lead with regards to the original, intact scene, right after the crime had been discovered.) The women told him that the victim had been lying under the table, and they had stretched her out on the couch. He saw from the injuries that she had been beaten up. The victim could not speak, but was conscious. Dezsi came around once muttering something, but the two women did not let him in.

The presiding judge - overruling the objection of the defence - reads the testimony that was made during the investigation by the late Mrs Albert Pusoma, who passed away during the trial.

Heves County Prosecutor's Office, Eger, 24 February 1995

Official note

$\mathrm{XY}$ has asked for a hearing today. He relates that he, as a cell mate of DP, acquired information about the case, that - as he understands - was used by the police, but the benefits and the plea bargain promised in return have not occurred. He has more information about DP's case and another, yet unsolved, murder case, but he would not give it out for free.

Heves County Court, Eger, 08.30, 3 March 1995

DP's third court session

(The central issue of the session is to establish how the police have taken hold of the "Confession of guilt" written by DP. In the course of the evidentiary process the court once again hears XY, the police officers who took part in the investigation, the prosecutor who supervised the case, and the lawyer who was representing XY then. The court confronts XY several times with the officers to resolve the apparent contradictions, but without success. The court does not inquire especially into the question of the conditions under which the letter was written and given to XY. The witness evidence of Aunt Rozi's other neighbour, who was also present when the victim was found, is inserted between the hearings of XY and the police officers.)

$\mathrm{XY}$ declares that he wants to make a testimony again to complete what was said at the previous session. (He asks the court to let his lawyer be present during his hearing, but the court denies his motion, claiming that the witness has no right for legal representation.) XY relates that the police approached him to acquire information about DP's case at around the middle of May 1994. XY was in a common cell with DP from 24 or 26 May. XY applied for a hearing to the prosecutor through his lawyer in the hope of a plea bargain. Then he stated that the document was not in the prison building any more. The prosecutor told him that he had heard about the bargain and approved it. Answering questions XY tells that he does not know why he said to the prosecutor that the document had been deposited outside 
the prison while in fact he was keeping it during that time. (The modification, allowing the plea bargain before the submission of the indictment, of the Police Act and the Criminal Process Code [CPC hereafter] came into effect on 1 October 1994.) He handed the document over to the police on 10 October. Concerning the handing over and the signing of the official record of it, he declares that "it happened because of intimidation and extortion." He furthermore states that DP wrote the document of his own will asking him to pass it to his lawyer.

The police officers deny that they would make promises of a plea bargain for XY or blackmail him in any way. According to their statement, XY offered his help voluntarily and gave the document to them on 10 October 1994. (They cannot answer the question of how it could be possible that he had kept the document and gave it to them only in October.) Answering the prosecutor's question, the officer who supervised the investigation relates that XY's lawyer tried to attain a release for XY. When it did not occur, the lawyer phoned him declaring that there would be an acquittal in DP's case - XY would confess that he had acted under duress.

The above mentioned prosecutor sets forth that when XY applied to him for the plea bargain he said that he had already deposited the document outside the prison because he did not want to endanger the bargain.

$\mathrm{XY}$ 's former defence lawyer refuses to testify on the grounds of his obligation of confidentiality.

Aunt Rozi's other neighbour who was present when the victim was found on 17 March 1994 corroborates the story that was heard at the previous session.

\section{LEGAL STORIES}

The matter of the case consists of the above introduced documents, that is, the pieces of reality and narrations that are moulded into various forms by the courts and the lawyers to ground their decisions, sentences, and legal reasoning during the legal process. The police records and the bill of indictment - which is the first to try to summarise the facts of the case and to place them in a coherent narrative frame - have the same nature as the "facts" established in the sentence of the court. The latter though has the peculiar character of being capable of replacing reality and of discrediting any other stories.

I shall relate the legal stories below - although I discuss the legal arguments only in the depth needed to understand DP's story and the circumstances of the birth of its artistic reflections.

Heves County Court, Eger, 19 April 1995

Sentence

(The sentence deals in detail with the personality of the victim and with the events that had occurred before the actual assault to enlighten the motives of the crime.) Aunt Rozi's daughter and her husband arrived at approximately 9.00. to help her in the work around the house. Dezsi had already been working there pruning the fruit trees. DP, who had gone to the public well for water around 10 o'clock, asked to be let in to give him a hand. At noon, Aunt Rozi's daughter made soup and warmed up the already prepared stuffed cabbage. When she realised that the food would not be enough for everybody, she asked her mother to tell DP that he had not been invited. And the "strong-willed" Aunt Rozi acted accordingly: she told DP to go home, he had not been invited, therefore he would not get lunch either. DP returned to help between 13.00 and 14.00 . Then the victim's daughter felt pity for him 
and asked her husband to offer him some wine. So Aunt Rozi's son-in-law invited DP, and gave him two glasses of wine. Dezsi and DP finished working around 16.00, and they left together. The victim's daughter and son-in-law also departed around 5 o'clock. About 6 o'clock in the evening DP thought that he would go back to Aunt Rozi to ask for his wage. He approached the victim's house from the back, from the direction of the garden, and he went into the house. Aunt Rozi was having a conversation with one of her neighbours in the meantime, with her back to DP who was making his way into the house, so she could not notice him. Returning into the house, Aunt Rozi found herself face to face with DP, who demanded his wage. The victim expelled him, and then he started to assault her. After this, he began to search for money. He rummaged the kitchen and pulled out the drawers of the furniture in the living room, but he did not find the money stored on the top of the cupboard. Eventually, DP left the premises. In the evening hours, when they were watching TV, Aunt Juliska asked Aunt Manci what DP had been doing in Aunt Rozi's house, but Aunt Manci did not pay attention to the remark. The next morning, around seven o'clock, one of the neighbours realised that Aunt Rozi's chimney was not smoking. She went to the victim's house, peered through the window, and saw Aunt Rozi lying under the table. She called the other neighbour right afterwards, with whom they entered the house, lifted the victim up from under the table and laid her on the bed. The victim was unconscious, her face and the furniture around was blood-stained. The neighbours immediately called the doctor. Aunt Rozi was transported to the hospital, but she did not regain consciousness, and passed away two days later, on 18 March. There was only an indirect causality between the assault and the death of the victim.

This story has been accepted as authentic by the court considering three pieces of evidence: The outcome of the odour lead identification, Aunt Juliska's testimony, and DP's autograph "Confession of guilt".

Regarding the odour lead identification, the court explains that the lead is undoubtedly identical with DP's odour, and it was recorded in front of the cupboard standing in the living room. Although at the explanation of the latter fact - which would evidently imply that DP had also been in the room, not only in the kitchen - the judge himself became confused. (For this can literally be read in the sentence: "During the hearing by the prosecutor the accused confessed that the cupboard had been in the kitchen. Contrary to the defence of the accused, the fact can beyond doubt be established from the data and the enclosed photos of the record that the cupboard had been in the kitchen.")

As for the acceptance of Aunt Juliska's testimony - that can support that DP entered Aunt Rozi's house - the court touches upon the fact that the fourth expert (whom the court asked to supervise the earlier opinions after the second session) also has found it unreliable, because the repeated questioning can trigger (involuntary) learning processes in the mind of the mentally impaired witness. Notwithstanding, the court has accepted her testimony as evidence, because the witness had mentioned her observation to Aunt Manci before her hearing took place. (Then why should four experts be heard about this?)

DP's "confession of guilt" appears in full length in the sentence: "Confession of guilt, Dénes Pusoma, by himself, I want to tell you the followings. I admit that on, maybe, 16 March 1994, but I'm no longer sure of it, on the day when I pruned in [...] Rozi's garden, I went back to her in the evening hours to demand the wage for the pruning. I took it badly too that she had offered me neither lunch, nor wine. She told me that she wouldn't pay anything and I should get out, and I became very angry with her then, and I remember that I hit her several times, but only because I got mad at her. I don't remember anything else that I have done to her. When I was leaving I saw that her face was bloody and she got laid 
on the floor. When I realised what had happened to her, I quickly ran away, and went home into my bed. This, what I've done to her, I didn't mean to, I just went for my money. I take the responsibility for my deed. Dénes Pusoma, Dated 19 VI 1994." According to the graphologist's undoubted opinion, the document was written in DP'S hand. XY testifies that DP voluntarily handed the document over to him, and DP had been forced by no means to write it and hand it over . "The County Court held the opinion that the handwritten document was conveyed to the investigating authorities by due proceedings." (What would have been an unlawful way?)

On the basis of these pieces of evidence, the court declares DP guilty of fatal assault and attempted robbery, and sentences him to six years in prison.

For neither the prosecutor, nor DP, nor his appointed defence lawyer appealed against the sentence, it became conclusive on 24 May 1995.

Heves County Court, Eger, 30 May 1996

Decree

The court orders the interruption of DP's serving of the sentence, for Alex Danó (henceforth AD) has confessed to the murder of Mrs Albert Pusoma - the crime which DP was sentenced for.

Heves County Court, Eger, 28 December 1996

Sentence

By its sentence delivered in the process of retrial, the court acquits DP of the crime with which he had been accused. AD has admitted and the supplementary investigation has corroborated that the crime was committed by AD. "Due to the evidence that have been brought to light in the retrial process, primarily AD's confession and the report of the medical expert, the evidence on which the first trial court based its verdict have lost their conclusiveness: especially the testimonies of [Aunt Juliska] and [XY], the record of the odour identification, and the material proof titled 'Confession of guilt'."

Heves County Court, Eger, 8 January 1997

EM, as DP's counsel, brings an action against the Hungarian State (hereafter HS) in which he demands 260,000 HUF compensation for the pecuniary and non-pecuniary damages caused by the innocently served 13 months pre-trial detention and the 13 months and 7 days in prison.

With its decree dated on 13 January, the Heves County Court (henceforth HCC) passes the case to the Eger City Court (hereafter ECC) as a civil law court of first instance. Several procedural steps, unimportant for our story at hand, follow hereafter. The ECC schedules the court session for six months later, for 29 October 1997.

\section{Budapest, 14 March 1997}

An article is published in the newspaper, Blikk, about the case with the title of "Two years served innocently".

Budapest, 16 June 1997

A documentary programme, titled "Sentenced for six years by mistake", DP's case is broadcast on Radio Kossuth and Radio Petöfi. 
Ivád, 6 August 1997

One year and three months after he was set free, eight months after his acquittal, and seven months after the damage claim was brought to the court, DP commits suicide.

Eger, 13 August 1997

A report is published in the Heves County Chronicle about the funeral of DP under the title of "Left no debt behind". From the report it turns out that DP sold his house and cleared all his debts before his death.

Budapest, 12 September 1997

Katalin Gönczöl, the Parliamentary Commissioner for Fundamental Rights, sends her annual report to the Legal Aid Bureau of National and Ethnic Minorities (henceforth: NEKI). In her report, the Ombudsman proposes the Parliamentary Commission for Constitutional and Judicial Matters to abrogate those paragraphs of the CPC which exclude the compensation of damages suffered by the innocently sentenced persons - namely point b./, section (3) of $\S 383$ of CPC (... [the sentenced] tried to deceive the authorities, thus obstructing the successful investigation ...); point a./, section (2) of $\S 384$ (... [the sentenced] concealed those facts or evidence on which the sentence delivered in the re-trial process had been established...), and point b./, section (2) of the $\S 384$ (...[the sentenced] did not appeal the sentence of the trial court ...) - as she finds these paragraphs unconstitutional.

Police Headquarters, Eger, 23 September 1997

The police establish the fact that the cause of DP's death is self-hanging and that no sign of foreign intervention has been found.

After this, EM begins to search for DP's inheritors, which takes several months. At the court session of the ECC, held on 29 October 1997, EM announces DP's death, and the court suspends the trial by its decree until the interceding of the heirs in trial. One year passes till EM identifies the inheritors and procures the necessary documents of probate. In October 1998, HS submits its counter claim for the first time in the case to the ECC in which the state motions the rejection of the damage claim on the grounds that DP did not appeal the sentence of the trial court (b./ (2) § 384 CPC), did not confess before the court, and wrote a confession of guilt (b./ (3) $\S 383$ CPC). HS furthermore asks for the attachment of the record of DP's trial to the file.

The ECC holds its first session on 7 April 1999. In its affidavit of defence, HS expounds that DP acted suspiciously, for he harassed the victim. In his response, EM argues that DP could not know that Aunt Rozi would be a victim of murder later, so he could not intentionally attract suspicion by his occasional presence at the crime scene. The parties jointly ask the attachment of the record of the investigation of DP's case to the file, and the suspension of the trial until this is done, which the court orders, indeed, in its decree.

The HCC sends the record of the investigation on 29 April 1999 to the ECC. Afterwards, ME asks the ECC to re-open the trial, and to reconsider the circumstances of the writing of the "Confession of guilt" on the basis of the earlier records and re-hearing of XY. In its affidavit, HS asks for the rejection of EM's claim, taking two main factors into consideration: first, that DP did not appeal the sentence of the trial court (b./ (2) § 384 CPC). Second, that DP deliberately deceived the authorities by declining the confession before the court, and by intentionally acting suspiciously during the investigation (b./ (3) $\S$ $383 \mathrm{CPC}$ ). Furthermore HS asks the court, in case it upholds the damage claim, to consider 
the facts that DP was unemployed and had a criminal record, when it determines the amount of the compensation.

In its sentence, dated on 7 July 1999, the ECC upholds the primary argument of the defendant, and rejects the damage claim, taking into account that DP did not appeal the trial court's decision. In his appeal submitted to the HCC, EM now focuses only on the pre-trial detention and he decreases the demanded compensation to half of the original amount. In his argumentation he explains that DP's omitted appeal excludes only the compensation for the imposed punishment. The legal qualification of the imposed punishment cannot be applied to the time spent with the pre-trial detention, not even if it is included in the punishment later. That is, the pre-trial detention is not a punishment "brought forward". Furthermore, EM emphasizes that the ECC based its verdict on a sentence that had been earlier quashed.

The HCC, as appellate court in civil law cases, partly upholds the plaintiff's appeal in its sentence dated on 30 October 1999. The court establishes that EM has rightly argued that the pre-trial detention does not have the same legal qualification as the punishment imposed by the sentence. The appellate court orders the first instance court to resume the evidentiary process without leaning on the facts established in the previously quashed sentence. The appellate court orders moreover that the ECC ought to look into the circumstances of the origin of the "Confession of guilt" independently from the earlier investigation that was conducted in the criminal case.

The resumed trial before the ECC lasts nearly two years, partly because the court cannot summon XY, and partly because the record of the criminal case has been attached to the file of the case against AD. The sentence is delivered at last on 21 October 2001 in which the court accepts again the secondary arguments formerly propounded by HS. On the basis of these (DP deceived the investigating authorities, and acted suspiciously intentionally), the court rejects the damage claim; moreover, it establishes that XY has made no testimony of any value during the resumed evidentiary process.

Among others, EM expounds in his appeal that the ECC did not look for any evidence. It did not resolve the contradiction between DP's and his mother's testimony: it cannot be known which one told the truth. Anyway, it could not be DP's intention to obstruct AD's arrest; at the most, he only wanted to save himself. The dream of the accused cannot be qualified as evidence. Neither could DP do anything about the outcome of the odour lead identification; this evidence lost its conclusiveness; DP could not hinder the successful investigation with this. DP cannot be blamed, for the investigating authorities ignored those clues which could lead to the real perpetrator. (The strangers mentioned in the first testimony of Aunt Manci; the alien footprints noticed by the innkeeper; also, the blood-stained dress that was found in the living room - just a few meters away from the spot where DP's odour was allegedly recorded - in the drawer of another cupboard. Most importantly, both the victim's and AD's blood were identified in the stain by the serological inquiry during the resumed investigation. The court did not inquire about the circumstances of the origin of the "Confession of guilt"; XY did not make any valuable testimony. DP did not intend to give the document to the authorities. It was in XY's interest to secure the document, and he applied "police methods" to get hold of it. It cannot be known how XY was able to hide the document in his cell - while, in all probability, it was with his lawyer during that time. In its sentence delivered in AD's case, the HCC touched upon the question of why DP had no right to compensation - this part of the sentence had been quashed by the Supreme Court.

In his supplementary affidavit, dated on 11 February 2002, EM tries to prove for the last time that the sentence delivered in DP's case was not only mistaken, but it could occur 
only as part of a process that is unlawful altogether, so its factual elements should not be applied as a basis for the deliberation of the matter of compensation. The defendant HS does not want to admit even the most conspicuous breaches of law. For example, the police did not follow the rules for the use of official witnesses during the hearing of Mrs Albert Pusoma. When DP was heard still as a witness, his mother was already qualified as "the mother of the accused" in the record-formula. DP's mother was not warned that she was not obliged to make a confession. For "tactical reasons" DP had been interrogated far more times than the number of properly recorded occasions. DP was not informed about his right to remain silent, even when he was heard as an accused. In the beginning of the record of the "oneiromancy", two officers' names appear in the heading, while three signed the record. DP had practically no defence lawyer during the whole investigation process. The rubric for choosing a lawyer was not even filled out in the record-formula when he was first heard as a suspect. DP did not intend to write his "Confession of guilt" for the authorities, but for XY's lawyer, because he himself did not have any counsel.

Nevertheless, the HCC reinforces the decision of the first instance court in February 2002, and this is the moment when Elemér Magyar sets out to write the drama.

\section{THE AUTHOR}

Elemér Magyar had been working as public prosecutor for two decades in Eger, when, two years before the democratic turn, he quit the Office for political reasons. He contacted the members of the dissident democratic opposition, with Ferenc Köszeg (the founder and first president of the Hungarian Helsinki Committee) and Imre Furmann among them. He regularly wrote articles for the Beszélö [Speaker], the samizdat paper of the democratic opposition. After 1989, he established a private praxis specialising himself mainly in criminal cases. He worked for more than a decade as a local representative of the Legal Aid Bureau of National and Ethnic Minorities (NEKI) - which was founded by Furmann in 1994 - assuring free legal assistance to the mainly Roma clients.

His first book, A Handbook for Beginner Criminals, was published in $2001 .^{5}$ This work is a collection of humorous stories and anecdotes, a kind of pamphlet-textbook of criminology, which allows an insight into the dim back allies of the Hungarian judicature. It casts a sharp light on the anomalies of the work of the law enforcement that the author experienced throughout his long legal career, as public prosecutor and criminal defence lawyer.

Magyar became involved in the Pusoma case as the representative of the NEKI in 1997. Magyar represented the innocently sentenced Pusoma and, after his suicide, his inheritors in the civil litigation of the damage claim filed against the Hungarian State. Magyar started writing a documentary drama from the case in 2002 after the damage claim was dismissed by a non-appealable sentence, and he put the first version of the piece on the internet by the end of the year. Later he re-wrote the drama and published it in book format in 2005 under the title of Black White. ${ }^{6}$ In that year Norbert Komenczi made a documentary film of the Pusoma case, and Ragályi approached Magyar with the plan of an art-film whose screenplay they wrote together from the drama.

\footnotetext{
5 Elemér Magyar, Kezdő bünözők kézikönyve [A Handbook for Beginner Criminals] (BBS-Info Kft 2001).

${ }^{6}$ Elemér Magyar, Fekete fehér [Black White] (BBS-Info Kft 2005).
} 
After the première of the film, which caused a sensation, Magyar, "the Gypsies' lawyer" became an outcast in the local legal community ${ }^{7}$ - the same way as it had happened to Dénes Pusoma in his village a decade earlier - and he soon retired from legal work and became a full time writer. He finished the Handbook for Beginner Law Enforcers, the continuation of the Handbook for Beginner Criminals. Last year, his comedy - Closed Chain: A Comedy of Crimes - was first performed in the theatre of Eger. ${ }^{8}$ His new comedy, A Wheelbarrow of Scones was ranked as the $7^{\text {th }}$ best drama in the 2013 Weöres Sándor drama competition. ${ }^{9}$ More recently he is working on his new book, Railed Academy, which is written in the same vein as his "handbooks".

\section{THE DRAMA}

If we look at the work from the "law and literature" perspective then we can consider it as a piece of "legal storytelling". ${ }^{10}$ Its unique feature lies in the fact that the author is a lawyer, but the narrator is an under-class man.

The plot of the drama closely follows the legal raw material of the case, but it is mostly set in the prison. We can understand the story-line foremost from the conversations between Pusoma (his name is Suha in the drama) and his cell mates. From time to time, Suha is brought to be interrogated - first by the police, later by the court.

One layer of the piece lets us take a look into the depressing world of the prison, where Suha - as Pusoma did in the outside world - finds himself at the lowest position of the hierarchy. Nevertheless, due to the close interdependence, a kind of solidarity is formed between the "old toughs" (recidivist criminals) and the ignorant new inmate. But his cell mates are giving advice in vain to Suha, who cannot understand how he became an accused from witness in the murder case. Suha is always speaking and keeping silent at the wrong time. He even tells his dream to the police in which he sees the victim lying at the crime scene (just in the same way as it really happened), but, when it would be appropriate to do it, he does not say anything in his own defence before the court, and he does not appeal the sentence.

Suha's dreams are inserted in the structure of the plot, and they are worth a detour. In the course of the criminal process, psychiatric experts investigated Pusoma, and they concluded that he was suffering from personality disorder: he had a psychopathic personality with primitive characteristics, and he developed a lot of dissociative psychic mechanisms. He escaped from the unwanted personal contacts by slipping into psychogenic illusionistic

${ }^{7}$ His colleagues coined the nickname "Putricelli" for him about this time. (This nickname refers to the popular American lawyer series, Petrocelli, on the one hand. The "putri" is the Hungarian name of the Gypsies' shaky huts, on the other hand.) E. Magyar's personal communication.

8 The plot of the comedy starts with an escaped prisoner's breaking into the house of a retired judge, and it soon turns out that the perpetrator was previously convicted by this very judge...

9 The protagonists of the satire are the members of a couple who have been living a simple life but suddenly become serial killers within just a few hours because of some pressing financial difficulties...

10 About "legal storytelling" see e.g. Richard Delgado, 'Storytelling for Oppositionists and Others. A Plea for Narrative' (1989) 87 Michigan Law Review 2411-2441. Mary I. Coombs, 'Outsider Scholarship. The Law Review Stories' (1992) 63 University of Colorado Law Review 683-716. Daniel A. Farber and Susanna Sherry, 'Telling Stories out of School. An Essay on Legal Narratives' (1993) 35 Stanford Law Review 807-855. 
paralogism. At his third interrogation - this was rather the thirteenth, because, as it later turned out from the files of the investigation, the detectives did not record every hearing for "tactical reasons" -, tormented by the physical and psychical harassment, he told that he had seen the victim in his dream. Although the photos of the crime scene had previously been shown to Pusoma, his statement about his dream was qualified as hard evidence both by the prosecution and the court. So, the appearance of the dreams in the piece has a double meaning: on one level of interpretation, it illustrates how a mentally ill man perceives reality, but on another level, they cast a light on the kafkaesque, terrifying surrealism of the reality of Hungarian jurisdiction.

Another layer of the drama explains how Pusoma's "admission of guilt" had been written (that was one of the main issues of the original case, too). Suha is taken into another cell, and his new cell mate makes him believe that if he admits to the crime that he never committed, then his lawyer will manage to set him free. This becomes understandable for the reader in the context of the inner reality of the drama, as well as Suha's desperation and disappointment after the euphoria of his unexpected release. A benevolent lawyer approaches him who promises millions for his innocently suffered troubles, and Suha starts dreaming about smoking Marlboro cigarettes, listening to Mozart discs and buying a chainsaw to make a living on his own... But he has to realise that every villager considers him a murderer and avoids him, and the promised millions are still not coming...

Dear Sir Lawyer Doctor! I applied for a loan from Pock-Marked Gazsi. He gave me first fifty, then seventy five. I have to pay back the double, you know how it is. Double or quits! I already called you several times about when that lawful innocent compensation sentence will come out. The other day, when we spoke on the phone, in the middle of big time laughs, because you were in a great mood, sure you had your name-day party with your dear family, it came through acoustically, You told me then, sure you do remember, calm down, Dénes, it'll not take a long time, not a long time. Pock-Marked Gazsi came with his lot. My legs were frostbitten in the forest in the meantime. I got to the hospital. They came after me there too, of course. I told them, that the Sir Doctor, who is an honest man, very seriously promised me that big money will come before long, maybe several millions, if we shall whine deftly. Don't be kidding us, they told me. But You told me that you'll get the money, Dénes, calm down, for it is due anyway. Because you were inside innocently, and what is due, is due. I am in a big trouble, I sold even my house for ten thousand, I don't know what will become of me. If You don't help, then, tell me, please, who on earth could help me...11

Most of the drama's text was composed from the excerpts taken from the original files of the criminal investigation and the trial. The author weaved stories from his "handbook" in this texture to animate the prison culture for the readers. The literary genius of the author can partly be found in his discovery of the hidden poesy of the original language of Pusoma who always slipped into dreams.

The importance of the drama - beyond the fact that it expresses the author's devotion to the cause and fate of the fallen and outcast people -, from the point of view of "law and literature", is that it shows that the fictive reality of the drama is much more truthful than the fiction accepted and enforced as reality by the court.

11 'Pusoma's last letter' in Elemér Magyar, Black White (manuscript reviewed by the author 2012) 66-67. 


\section{THE FILMS}

Two films were made from the Pusoma case, which considerably amplified the social effects of the literary piece. Norbert Komenci's documentary film, the Grinder, presented and enriched the legal material, ${ }^{12}$ while Elemér Ragályi's art film ${ }^{13}$ adapted the drama. The two films appropriately completed each other illuminating the case from an "outside" and an "inside" perspective.

The Grinder's virtue is that the director primarily strives for objectivity. To achieve this, not only the characters of the original story appear in the film and tell their part of the case, but also a journalist, Antal Izing, who represents the concerned citizen's point of view.

The film helps a lot in understanding the legal material. Pusoma's acquaintances are also interviewed - and not only those whose opinion is biased by racist hatred, but also those who understand the tragedy and feel empathy for Pusoma; the eye-witness, who is already unreliable at first glance; the cynical representative of the public prosecution office, who explains that the kind of errors like those committed in the Pusoma case can occur in any other investigation, too.

Izing's insight, what he formulated by the end of the film is quite noteworthy: according to him, there are not only two victims of the case - the murdered woman and the innocently sentenced Pusoma -, but three. The third one is the villagers' community itself, whose life was utterly disturbed by the tragic events, and they still have not been able to get over them after a decade. Izing makes another very educative note, when he summarises his opinion about the case: if Pusoma intentionally misled the investigatory authorities, then a rabbit might as well have done it.

It is not necessary to discuss the aesthetic values of Ragályi's film here - he won the prize for best direction with No Mercy at the $39^{\text {th }}$ Hungarian Film Exposition in 2007. For our purpose it is enough to point out that the film does not only authentically convey the message of the drama. The film representation of the dreams, for example, enhances the kafkaesque surrealism of the legal process, and also brings several hidden psychical structures to light, such as the victim's unconscious self-identification with the aggressor, and the distorted erotic aspects of the prison life. ${ }^{14}$

12 Daráló [Grinder], made by Filmplus Ltd. by the comission of Legal Aid Bureau of National and Ethnic Minorities, with the support of the Embassy of the Kingdom of the Netherlands, the Hungarian National Cultural Heritage and the Hungarian National Cultural Funds, Budapest 2005. Directed by Norbert Komenczi.

13 Nincs kegyelem [No Mercy], made by Tivoli-Filmprodukció Ltd. with the support of Duna Television, Hungarian Public Funds for Cinematography, Ministry of Education and Culture, National Radio and Television Council, Ministry of Social Services and Labour, Budapest 2006. Directed by Elemér Ragályi.

14 It is an important dramaturgical device in the movie that the victim's and the judge's sex is exchanged: the victim becomes a man, while the judge is changed into a female character. One of the most remarkable scenes of the film is Dénes's dream in which the judge descends from her pulpit and engages in a love-chatter with him, promising huge compensation for his innocently suffered punishment. 


\section{QUESTIONS INSTEAD OF CONCLUSION}

As I have already indicated, this paper does not aim to explore every important aspect of the Pusoma case, but only to shed light on the horizon of the possible further studies from the perspective of "law and literature". I would like to take them into account, one after the other, below.

Literary studies. The legal element has dominated the approach of "law and literature" in the present discussion of the case, albeit it offers questions especially for the literary studies, too. Thus the text of the drama could be analysed by applying the method of "close reading" and also from the point of view of intertextuality. ${ }^{15}$ That is, the way the texts of the police records, the court files and the stories of the "handbooks", written earlier by the author, are built into the text of the drama could also be examined.

Forensic sciences, forensic linguistics. After reading the legal documents and the literary works, the question of what happened in reality evidently arises, since the only thing that was written in the acquittal judgment is that the evidence established in the court of first instance "had lost their conclusiveness." How did the odour leads get into the living room? (Could it have happened when the neighbours cleaned up the ravaged kitchen before they called the doctor to Aunt Rozi?) How could the crime scene appear in DP's dream? (In EM's opinion, DP eventually went back to Aunt Rozi in the late ours to ask for his wage, but the real perpetrators had already left the scene by then. When DP saw what had happened, he immediately did what was the most reasonable for a Roma with a criminal record: he ran back home. I think another scenario may have happened: on the morning when the victim was found, Dezsi also appeared at the scene, and he could possibly inform DP in detail about what he had seen or heard before the police came. Nevertheless, the officers themselves also described the crime scene to DP, who was blessed with a vivid imagination, during his interrogation.)

As for the circumstances of the origin of the "Confession of guilt", it would be worth comparing the texts of DP's earlier letters and verbal statements with the text of the letter while applying the methods of forensic linguistics. For example, I find it strikingly suspicious that he should write the sentence, "I take the responsibility for my deed."; it is probable that it was not composed by DP. (It is enough if we remember the title of his previous letter: "The witness who became a pandour".)

Legal anthropology. What was the importance of the fact in the case that DP was a Roma? The case can be inspected from the point of view of the earlier studies that have been conducted on the legal position of the Romas, calling attention to the different forms of latent discrimination against them.

Criminology. The case could pose important questions for the students of criminal law. Is it acceptable that a mentally ill person - even if his sickness does not exclude his criminal responsibility - should be deprived of proper legal assistance during the whole evidentiary process? This question, of course, can also be formulated on a more general level, which leads us to the legal-sociological inquiry of the institution of appointed lawyer. Moreover, can those methods of the investigative authorities be really considered as lawful with which they elicited the evidence from DP, with the help of XY? As for the acceptance of the testimony of the mentally impaired witness, the following question could be posed: what are the limits of the judges' right to the free deliberation of evidence? If we take one more

15 See e.g. Tamás Nagy, 'Law, Literature and Intertextuality' (2012) 53/1 Acta Juridica Hungarica $62-71$. 
step, we get to the general theoretical problem of the role that the judges play in the evidentiary procedure.

Legal sociology. The social effects of the drama written from the case, and those of the films are worthy of the special attention of legal sociology. In my summarized opinion and I would immediately like to make it clear that the following statements are in need of further inquiries - the primary effect of the drama manifested itself in the subsequent nullification of the above mentioned rules of the CPC. The NEKI had already submitted a motion in 1997 to the Ombudsman of Fundamental Rights, and had also asked her to speak up before the Commission for Constitutional and Judicial Matters of the Parliament for the abrogation of those rules which excluded the rights of the innocently sentenced persons for compensation - point b./ of section (3) of $\S 383$ and points a./ and b./ of section (2) of $\S 384$ of the CPC. Later the NEKI applied to the Constitutional Court, but nothing happened for five years. When Magyar put the drama on the internet at the end of 2002 more than fifty thousand people visited the homepage by the end of the first month, and it gained wide publicity in the professional and political media. So, it was hardly a coincidence that the Constitutional Court announced the nullification of the CPC's rules in question just a few months later, in 2003. ${ }^{16}$

After the democratic turn, in the 1990's, the Hungarian judicature, as the "third branch of power", gained a considerably wide autonomy. Nevertheless, this great independence soon led to seclusion from the democratic political control, and to nepotism and contraselection causing the diminution of professionalism. After the millennium it became clear that the reform of the Hungarian judicial system was unavoidable. ${ }^{17}$ The Pusoma case, Magyar's drama and the two films appearing later all became the symbols of the necessity of these reforms, and they have sufficiently prepared the acceptance of these changes both in the political and the professional public opinion. So, neither was it a coincidence that after the premier of No Mercy the Heves County Court felt the need to hold a press conference to try to save its honour - rather unsuccessfully this time.

\section{LITERATURE}

Bencze, M. and Badó, A., 'Reforming the Hungarian Lay Justice System' in Cserne, P. et al. (eds), Theatrum Legale Mundi. Symbola Cs. Varga oblata (Szent István Társulat 2007) 1-13.

Coombs, M. I., 'Outsider Scholarship. The Law Review Stories' (1992) 63 University of Colorado Law Review 683-716.

Delgado, R., 'Storytelling for Oppositionists and Others. A Plea for Narrative' (1989) 87 Michigan Law Review 2411-2441.

Farber, D. A. and Sherry, S., 'Telling Stories out of School. An Essay on Legal Narratives' (1993) 35 Stanford Law Review 807-855.

Fleck, Z., 'Judicial Independence and Its Environment' in Priban, J. and Roberts, P. (eds), Systems of Justice in Transition (Ashgate 2003) 121-140.

Magyar, E., Fekete fehér [Black White] (BBS-Info Kft 2005).

Magyar, E., Kezdö bünözők kézikönyve [A Handbook for Beginner Criminals] (BBS-Info Kft 2001).

Nagy, T., 'Law, Literature and Intertextuality' (2012) 53/1 Acta Juridica Hungarica 62-71.

16 See 41/2003 (VII. 2.) AB [Hungarian Constitutional Court] decision.

17 Mátyás Bencze and Attila Badó, 'Reforming the Hungarian Lay Justice System' in Péter Cserne et al. (eds), Theatrum Legale Mundi. Symbola Cs. Varga oblata (Szent István Társulat 2007) 1-13. Zoltán Fleck, 'Judicial Independence and its Environment' in Jiri Priban and Pauline Roberts (eds.), Systems of Justice in Transition (Ashgate 2003) 121-140. 
Szilágyi, I. H., 'Law and Literature in Hungary. An Introduction’ (2012) 53/1 Acta Juridica Hungarica $1-6$.

Szilágyi, I. H. and Loss, S., 'Opening Scissors. The Legal Status of the Gypsy Minority in the Nowadays Hungary' (2002) 33/2-4 Rechtstheorie 483-494.

Szilágyi, I. H., 'The Roma Way' in Wagner, A. and Bhatia, V. K. (eds), Diversity and Tolerance in Socio Legal Context: Explorations in the Semiotics of Law (Ashegate 2009) 65-80.

White, H., 'The Burden of History' (1966) 5/2 History and Theory 111-134.

White, H., Metahistory: The Historical Imagination in Nineteenth Century Europe (John Hopkins 1973). 